\title{
Short communication: The gain-of-function Y581S polymorphism of the ABCG2 transporter increases secretion into milk of danofloxacin at the therapeutic dose for mastitis treatment
}

\author{
J. A. Otero, ${ }^{*} \dagger$ B. Barrera, ${ }^{*} \dagger$ A. de la Fuente, ${ }^{*}$ J. G. Prieto, ${ }^{\star} \ddagger$ M. Marqués, $†$ A. I. Álvarez, ${ }^{*}$ and G. Merino*${ }^{*}{ }^{1}$ \\ *Department of Biomedical Sciences-Physiology, Veterinary Faculty, and \\ †Instituto de Desarrollo Ganadero y Sanidad Animal (INDEGSAL), and \\ †Instituto de Biomedicina (IBIOMED), University of Leon, Campus de Vegazana 24071, Leon, Spain
}

\section{ABSTRACT}

The ATP-binding cassette transporter ABCG2 restricts the exposure of certain drugs and natural compounds in different tissues and organs. Its expression in the mammary gland is induced during lactation and is responsible for the active secretion of many compounds into milk, including antimicrobial agents. This particular function of ABCG2 may affect drug efficacy against mastitis and the potential presence of drug residues in the milk. Previous in vitro and in vivo studies showed increased transport of several compounds, including fluoroquinolones, by the bovine ABCG2 Y581S polymorphism. Our main purpose was to study the potential effect of this bovine ABCG2 polymorphism on the secretion into milk of the antimicrobial danofloxacin administered at the therapeutic dose of $6 \mathrm{mg} / \mathrm{kg}$ used for mastitis treatment. In addition, the effect of this polymorphism on the relative mRNA and protein levels of ABCG2 by quantitative real-time PCR and Western blot were studied. Danofloxacin $18 \%$ (6 mg/ $\mathrm{kg}$ ) was administered to $6 \mathrm{Y} / \mathrm{Y}$ homozygous and $5 \mathrm{Y} / \mathrm{S}$ heterozygous cows. Danofloxacin levels in milk and milk-toplasma concentration ratios were almost 1.5- and 2-fold higher, respectively, in $\mathrm{Y} / \mathrm{S}$ cows compared with the $\mathrm{Y} / \mathrm{Y}$ cows, showing a higher capacity of this variant to transport danofloxacin into milk. Furthermore, the higher activity of this polymorphism is not linked to higher ABCG2 mRNA or protein levels. These results demonstrate the relevant effect of the Y581S polymorphism of the bovine ABCG2 transporter in the secretion into milk of danofloxacin after administration of $6 \mathrm{mg} / \mathrm{kg}$, with potentially important consequences for mastitis treatment and for milk residue handling.

Key words: ABCG2, polymorphism, danofloxacin, milk secretion

Received April 25, 2014.

Accepted September 23, 2014.

${ }^{1}$ Corresponding author: gmerp@unileon.es

\section{Short Communication}

Fluoroquinolones are a group of broad-spectrum antimicrobials that act against several microorganisms, including gram-positive and gram-negative bacteria. Under systemic infectious processes, treatment of dairy livestock with antibiotics may result in direct economic losses for industry, farmers, and consumers, due either to the drug withdrawal periods in milk or to the potential presence of drug residues. Conversely, effective mastitis systemic treatment requires drugs to extensively penetrate into milk (Ziv, 1980), and therefore, in this case, concentration of antimicrobials into milk is desirable.

The ABCG2 transporter is one of the main factors involved in drug transfer into milk (Jonker et al., 2005), and, in its characterization, authors have obviously sought to avoid, control, and predict drug secretion into milk mediated by this protein (González-Lobato et al., 2014). Although the induced expression in the lactating mammary gland (Jonker et al., 2005) is not exclusive for this ABC transporter (Farke et al., 2008; Mani et al., 2009; Ito et al., 2014), a clear effect of ABCG2 in the veterinary medicine field related with drug secretion into milk has been reported by several groups (Real et al., 2011a; Mealey, 2013).

Cohen-Zinder et al. (2005) described a nonsynonymous SNP (A/C, rs43702337) encoding a substitution of a Tyr by a Ser at position 581 (Y581S) of bovine ABCG2. This genetic change was reported to alter milk yield and composition (Cohen-Zinder et al., 2005; Olsen et al., 2007). Later on, we presented this SNP as an in vitro gain-of-function polymorphism, revealing a higher capacity of the Y581S variant to transport antimicrobials (Merino et al., 2009; Real et al., 2011b). These data were recently corroborated in vivo, showing that cows carrying the Y581S polymorphism resulted in a 2 -fold increase in milk levels of danofloxacin administered at $1.25 \mathrm{mg} / \mathrm{kg}$ (2.5\% formulation; Otero et al., 2013). However, a formulation of danofloxacin $18 \%$ was recently developed to allow the delivery of a higher dose 


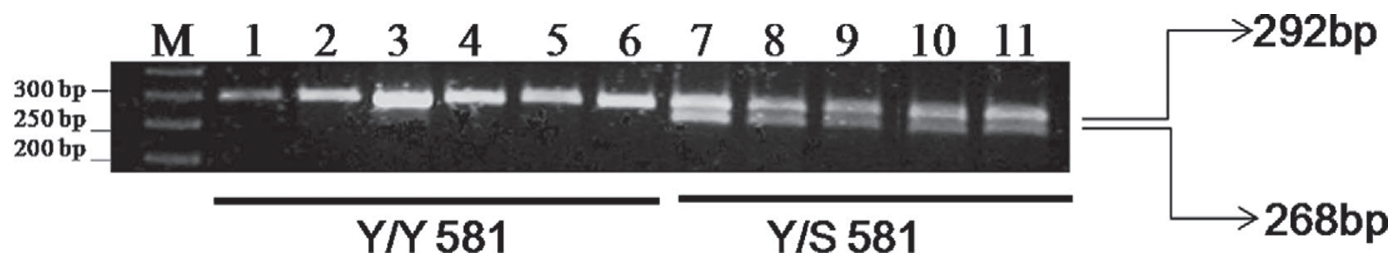

Figure 1. Genotyping of the Y581S polymorphism of the bovine ABCG2 gene by PCR-RFLP. Allele-specific genotyping of 6 homozygous $\mathrm{Y} / \mathrm{Y}$ and 5 heterozygous $\mathrm{Y} / \mathrm{S}$ animals.

$(6 \mathrm{mg} / \mathrm{kg})$. As fluoroquinolone antibacterial efficacy is dependent on the peak concentration obtained rather than the duration of plasma concentrations above the minimum inhibitory concentration (Rowan et al., 2004), the efficacy of the $18 \%$ formulation has advantages compared with the $2.5 \%$ formulation, as the former allows the administration of higher concentrations in a lower volume (Mestorino et al., 2009). Furthermore, this formulation has been reported as safe and effective in the treatment of pneumonia, enteritis, and mastitis with a single dose or at most 2 doses (Poutrel et al., 2008; Mestorino et al., 2009), with the drug reaching high concentrations in different ruminant species (Escudero et al., 2007), thus potentially reducing selection pressure for bacterial resistance (Martinez et al., 2006).

The effect of $\mathrm{ABC}$ transporters and their polymorphisms on drug pharmacokinetics and disposition can vary depending on the dose of drug administered; an effect of a specific SNP can be reported at only one dose, but not at others (Fukui et al., 2007), or even saturation of the ABC transporters can lead to nonlinear pharmacokinetics (Maeda et al., 2011; Adane et al. 2012). Because a reported effect at one dose (in our case $1.25 \mathrm{mg} / \mathrm{kg}$ of danofloxacin) does not guarantee an extension of the effect to other doses (in our case $6 \mathrm{mg} / \mathrm{kg}$ ), studying the effect of each transporter and SNP at each therapeutic dose is necessary. Therefore, the main aim of this work was to test the effect of the bovine Y581S SNP on secretion into milk of danofloxacin administered at $6 \mathrm{mg} / \mathrm{kg}$ (18\% formulation). In addition, the effect of this SNP on the ABCG2 mRNA and protein levels was also studied to test whether the in vivo effect of the polymorphic variant was associated to higher transcriptional rate or protein expression.

Animals were housed and handled according to institutional guidelines complying with European legislation (2010/63/EU). Lactating Holstein-breed cows aged 2 to $5 \mathrm{yr}$ and weighing 600 to $800 \mathrm{~kg}$ were used. The daily milk yield averaged $41 \pm 7 \mathrm{~kg}$. The cows were milked twice daily. The animals were free of parasites. Drinking water was available ad libitum for all cows. The experiments were performed on the private farm Garfi SAT located at Santa María del Monte del Condado, Leon (Spain).
The DNA for animal genotyping was extracted from hair follicles using Chelex 100 (Walsh et al., 1991) or from peripheral blood by a standard phenol-chloroform procedure. Genotypes were determined by the PCRRFLP method described by Komisarek and Dorynek (2009). After amplification of a 292-bp region of the $A B C G 2$ gene potentially containing the SNP and digestion with PstI (Thermo Fisher Scientific, Madrid, Spain), only the amplified products containing the SNP were targets of the restriction enzyme, with restriction fragments obtained of 268 and $24 \mathrm{bp}$ and only the $268 \mathrm{bp}$ band detected. We selected $5 \mathrm{Y} / \mathrm{S}$ and 6 $\mathrm{Y} / \mathrm{Y}$ lactating cows for further experiments (Figure 1); $\mathrm{S} / \mathrm{S}$ animals could not be found. Because Y581S SNP frequency can reach $20 \%$ in some Holstein populations (Ron et al., 2006), the heterozygous pattern is expected to be more common than homozygosity. Thus, the use of heterozygous animals for our study would be the most realistic scenario.

Animals were divided into 2 groups of $5 \mathrm{Y} / \mathrm{S}$ and $6 \mathrm{Y} / \mathrm{Y}$ cows for experimental design. Both groups received a single dose of $6 \mathrm{mg} / \mathrm{kg}$ of danofloxacin (Advocin 18\%, Pfizer, Cedex, France) subcutaneously in the neck. Blood samples were collected from the tail vein before the treatment and at 1, 5, 11, 24, 48, 72, and $96 \mathrm{~h}$ after danofloxacin administration. Milk samples were manually collected only from the front quarters for technical convenience at the same time points. No more sampling points were possible because of the private nature of the farm. Complete evacuation of the udder of each gland was performed to avoid a dilution effect during the normal milking routine (twice a day). Blood samples were centrifuged at 1,000 $\times g$ for $15 \mathrm{~min}$ at room temperature; plasma was collected and plasma and milk samples were stored at $-20^{\circ} \mathrm{C}$ until analysis.

The conditions for HPLC analysis of danofloxacin concentrations in plasma and milk were modified according to previously published methods (Cho et al., 2010). Ciprofloxacin at $1.25 \mu \mathrm{g} / \mathrm{mL}$ for the plasma sample extraction and ciprofloxacin at $5 \mu \mathrm{g} / \mathrm{mL}$ for the milk sample extraction was used as internal standard. We added $600 \mu \mathrm{L}$ of chloroform to each $100 \mu \mathrm{L}$ aliquot of sample; samples were shaken and the organic and water phases were separated by centrifugation at 5,000 
$\times g$ for 6 min at room temperature and evaporated to dryness under a nitrogen stream. The residue was reconstituted in $100 \mu \mathrm{L}$ of methanol and injected into the HPLC system consisting of a Waters 600 pump, a Waters 717 plus autosampler, a Waters 486 fluorescence detector (Waters Corporation, Milford, MA), and a $\mathrm{C}_{18}$ reversed-phase column (Synergi $4 \mathrm{~mm}$ Hydro RP 80A; Phenomenex, Torrance, CA). For plasma sample analyses, the mobile phase consisted of $25 \mathrm{mM}$ orthophosphoric acid $(\mathrm{pH}$ 3.0) in a ratio with acetonitrile $(80: 20 \mathrm{vol} / \mathrm{vol})$, and the flow rate of the mobile phase was set to $1.6 \mathrm{~mL} / \mathrm{min}$. For milk analyses, $1 \%$ triethylamine was added to $25 \mathrm{~m} M$ orthophosphoric acid (pH 3.0) and the flow rate was set to $1.85 \mathrm{~mL} / \mathrm{min}$. Sample detection was performed by fluorescence detection at 338 (excitation) and $425 \mathrm{~nm}$ (emission). Integration was performed using Millennium 32 software (Waters). The limits of detection were $6 \mathrm{ng} / \mathrm{mL}$ for plasma and $4 \mathrm{ng} / \mathrm{mL}$ for milk. The limits of quantification were $17 \mathrm{ng} / \mathrm{mL}$ for plasma and $13 \mathrm{ng} / \mathrm{mL}$ for milk. Plasma and milk concentrations for each animal were analyzed using a computer program (PK solution 2.0, Summit Research Services, Ashland, $\mathrm{OH}$ ) to obtain the estimated pharmacokinetic parameters.

For quantitative real-time (qRT)-PCR and Western blot analysis, total RNA and protein of heterozygous and homozygous animals were isolated from milk fat globules according to previously published methods (Maningat et al., 2009; Pisanu et al., 2011) before administration of the drug. Fat globules contain crescents of mammary epithelial cells, which have been reported as a high-quality RNA and protein source (Maningat et al., 2009; Pisanu et al., 2011)

For qRT-PCR analysis, cDNA synthesis was performed using High-Capacity cDNA Reverse Transcription Kit (Applied Biosystems, Carlsbad, CA) and oligo-dT primers, and qRT-PCR was performed using a Taq Man (Applied Biosystems)-based PCR assay, in accordance with manufacturer's instructions. Step One Plus Real-Time PCR System (Applied Biosystems) was used for thermocycling and to record changes in fluorescence. The PCR reaction was initiated with preincubation at $95^{\circ} \mathrm{C}$ for $20 \mathrm{~s}$ followed by 40 cycles of $95^{\circ} \mathrm{C}$ for $1 \mathrm{~s}$ and $60^{\circ} \mathrm{C}$ for $20 \mathrm{~s}$. Results were analyzed with Step One software v2.0. Relative gene expression was normalized to the expression of $\beta$-actin housekeeping gene using the threshold cycle $\left(\mathrm{C}_{\mathrm{T}}\right)$ method, $2^{\Delta \mathrm{CT}}$.

For Western blot analysis, $0.2 \mu \mathrm{g}$ of protein samples were resolved in an $8 \%$ SDS-polyacrylamide gel and electrotransferred to nitrocellulose Hybond membranes (GE Healthcare, Chalfont St. Giles, UK). The membranes were blocked with $1 \%$ skim milk then incubated overnight at $4{ }^{\circ} \mathrm{C}$ with anti-mouse BXP-53 monoclonal antibody (Monosan, Uden, the Netherlands) in a 1:250 dilution. Secondary horseradish peroxidase-conjugated antibody and Immobilon Western kit (Millipore Corporation, Billerica, MA) were used to visualize ABCG2.

Statistical analysis for significant differences was performed using the 2-tailed Student's $t$-test. A probability of $P<0.05$ was considered statistically significant.

Regarding plasma levels and plasma pharmacokinetic parameters (Figure 2, Table 1), although a tendency to lower area under the concentration curve $\left(\mathbf{A U C}_{0-\infty}\right)$ in the $\mathrm{Y} / \mathrm{S}$ animals was shown $(10.83 \pm 3.38$ vs. 7.88 $\pm 2.21 \mu \mathrm{g} \cdot \mathrm{h} / \mathrm{mL}$ for $\mathrm{Y} / \mathrm{Y}$ and $\mathrm{Y} / \mathrm{S}$ cows, respectively), no significant differences $(P=0.16)$ in the different parameters between both groups were noted in our experimental conditions $(n=5-6)$. Plasma levels for both groups of animals were quite similar to those obtained in previous pharmacokinetic studies of danofloxacin in cows at $6 \mathrm{mg} / \mathrm{kg}$ (Mestorino et al., 2009).

In contrast to plasma pharmacokinetic parameters, milk pharmacokinetic parameters (Table 1) such as $\mathrm{AUC}_{0-\infty}$ and $\mathrm{C}_{\max }$ (maximum concentration) were more than 2-fold higher for $\mathrm{Y} / \mathrm{Y}$ animals and 3-fold higher for $\mathrm{Y} / \mathrm{S}$ cows than those previously published by Mestorino et al. (2009). These discrepancies could be attributed to differences in the experimental conditions between both reports, such as the different daily milk production (10-25 vs. $38-47 \mathrm{~kg}$ in our animals), different animal weight (500-650 vs. $600-800 \mathrm{~kg}$ in our study), different milk sampling procedure (from all quarters vs. from only front quarters in our case), or a likely different diet. It has been reported that differences in diet

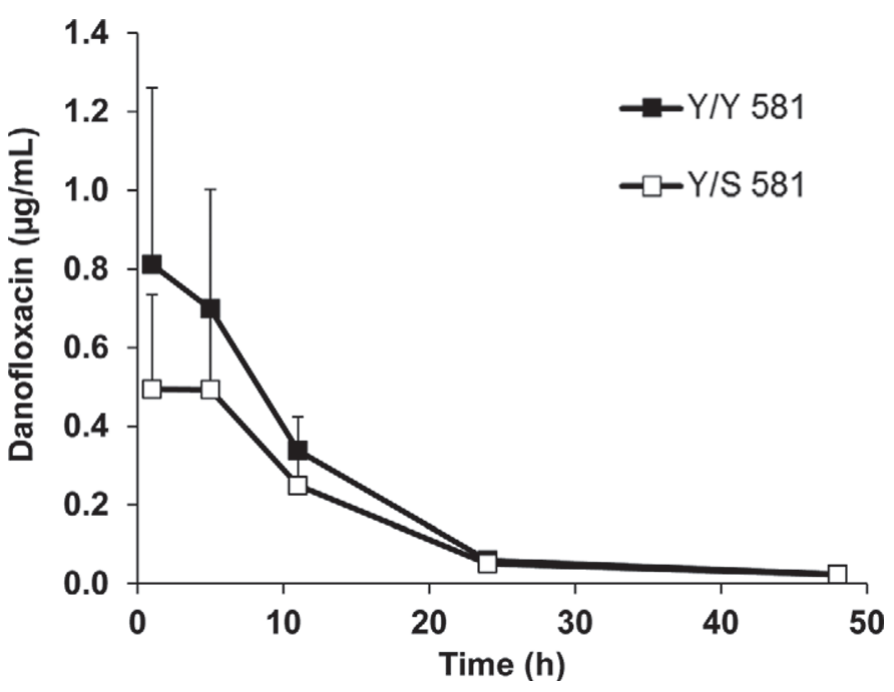

Figure 2. Plasma concentrations of danofloxacin after its subcutaneous administration at a dosage of $6 \mathrm{mg} / \mathrm{kg}$ to Y $/ \mathrm{S} 581$ heterozygous and Y/Y 581 homozygous lactating cows genotyped for the Y581S polymorphism of the bovine $A B C G 2$ gene. Plasma samples were collected at several points over $96 \mathrm{~h}$. Concentrations at 72 and $96 \mathrm{~h}$ were undetectable. The results are presented as means; error bars indicate SD. $\mathrm{Y} / \mathrm{Y}$ cows $\mathrm{n}=6 ; \mathrm{Y} / \mathrm{S}$ cows $\mathrm{n}=5$. 
Table 1. Pharmacokinetic parameters (means \pm SD) of danofloxacin in plasma and milk after subcutaneous administration at a dosage of 6 $\mathrm{mg} / \mathrm{kg}$ in $\mathrm{Y} / \mathrm{Y}(\mathrm{n}=6)$ and $\mathrm{Y} / \mathrm{S}$ cows $(\mathrm{n}=5)$ genotyped for the $\mathrm{Y} 581 \mathrm{~S}$ polymorphism of the bovine $A B C G 2$ gene

\begin{tabular}{|c|c|c|}
\hline Parameter $^{1}$ & Y/Y 581 & Y/S 581 \\
\hline \multicolumn{3}{|l|}{ Plasma } \\
\hline $\operatorname{AUC}_{0-\rightarrow \infty}(\mu \mathrm{g} \cdot \mathrm{h} / \mathrm{mL})$ & $10.83 \pm 3.38$ & $7.88 \pm 2.21$ \\
\hline $\mathrm{C}_{\max }(\mu \mathrm{g} / \mathrm{mL})$ & $0.84 \pm 0.40$ & $0.55 \pm 0.22$ \\
\hline $\operatorname{MRT}(\mathrm{h})$ & $13.50 \pm 1.63$ & $14.83 \pm 2.06$ \\
\hline $\mathrm{T}_{\max }(\mathrm{h})$ & $3.00 \pm 2.00$ & $3.40 \pm 1.95$ \\
\hline $\mathrm{T}_{1 / 2 \text { el }}(\mathrm{h})$ & $9.36 \pm 1.13$ & $10.28 \pm 1.43$ \\
\hline \multicolumn{3}{|l|}{ Milk } \\
\hline $\mathrm{AUC}_{0-\rightarrow \infty}(\mu \mathrm{g} \cdot \mathrm{h} / \mathrm{mL})$ & $33.80 \pm 7.15^{\mathrm{a}}$ & $49.94 \pm 15.14^{\mathrm{b}}$ \\
\hline $\mathrm{C}_{\max }(\mu \mathrm{g} / \mathrm{mL})$ & $2.88 \pm 1.14$ & $4.32 \pm 2.36$ \\
\hline MRT (h) & $14.07 \pm 0.75$ & $13.51 \pm 0.82$ \\
\hline $\mathrm{T}_{\max }(\mathrm{h})$ & $7.00 \pm 3.09$ & $7.10 \pm 3.28$ \\
\hline $\mathrm{T}_{1 / 2 \text { el }}(\mathrm{h})$ & $9.75 \pm 0.52$ & $9.36 \pm 0.56$ \\
\hline AUC Milk/plasma & $3.42 \pm 1.32^{\mathrm{a}}$ & $7.02 \pm 3.12^{\mathrm{b}}$ \\
\hline
\end{tabular}

${ }^{\mathrm{a}, \mathrm{b}}$ Means within a row with different superscripts differ $(P<0.05)$.

${ }^{1} \mathrm{AUC}=$ area under the concentration curve; $\mathrm{C}_{\max }=$ maximum concentration; $\mathrm{MRT}=$ mean residence time; $\mathrm{T}_{1 / 2 \mathrm{el}}=$ elimination half-life; $\mathrm{T}_{\max }=$ time to peak concentration.

composition, such as the presence of natural flavonoids, can change the amount of drug transported into milk (Pérez et al., 2009).

Regarding the genotype-driven differences in secretion of danofloxacin into milk (Figure 3, Table 1), our analyses showed that milk $\mathrm{AUC}_{0-\infty}$ values were 1.5 -fold higher for cows carrying the polymorphism (33.80 \pm 7.15 vs. $49.94 \pm 15.14 \mu \mathrm{g} \cdot \mathrm{h} / \mathrm{mL}$ for $\mathrm{Y} / \mathrm{Y}$ and $\mathrm{Y} / \mathrm{S}$ cows, respectively; $P<0.05$ ). This increase in danofloxacin levels in milk (1.5-fold) is lower than that previously observed for administration of $1.25 \mathrm{mg} / \mathrm{kg}$ (2-fold), thus illustrating some differences in the effect of the Y581S SNP depending on the administered dose.

To evaluate the effect of the transporter in the transfer of danofloxacin from plasma into milk, we calculated AUC milk-to-plasma ratios $(3.42 \pm 1.32$ vs. $7.02 \pm 3.12$ for $\mathrm{Y} / \mathrm{Y}$ and $\mathrm{Y} / \mathrm{S}$ cows, respectively; $P<0.05$ ), showing 2-fold higher values for the $\mathrm{Y} / \mathrm{S}$ animals. This effect is similar to the one reported by Otero et al. (2013) after the administration of danofloxacin at $1.25 \mathrm{mg} /$ $\mathrm{kg}$ with a 2-fold difference observed in the AUC milkto-plasma ratios between both genotypes. Our results show that the Y581S SNP in ABCG2 also increases the secretion into milk of danofloxacin administered at 6 $\mathrm{mg} / \mathrm{kg}$ (18\% solution).

One important issue in these studies regarding Y581S SNP of bovine ABCG2 is to determine whether the higher activity of the SNP is due to a higher capacity of the variant to transfer danofloxacin into milk or to an increased expression of the transporter. Several reports suggest that certain SNP can increase the expression of their mRNA transcripts or proteins (Wojnowski and Brockmoller, 2004; Visser et al., 2014). Even for heterozygous individuals it has been reported that SNP could alter the expression of ABCG2 (Kobayashi et al., 2005). To check ABCG2 mRNA and protein expression in the mammary gland of the 2 sets of cows $(\mathrm{Y} / \mathrm{S}$ heterozygous and $\mathrm{Y} / \mathrm{Y}$ homozygous), we performed reverse transcription-PCR and Western blot analysis from RNA and protein isolated from the milk fat globules. Variability in the relative ABCG2 mRNA levels was very high between individuals in both groups (Figure 4A). Comparison of protein levels revealed that Y581S did not cause an increased expression on the transporter (Figure 4B). These data suggest that the Y581S SNP of the bovine ABCG2 transporter probably acts in vivo as a gain-of-function polymorphism with higher capacity, as shown previously in MDCK-II in vitro models (Real et al., 2011b).

Antimicrobial therapy against mastitis includes intramammary application, systemic application, or a combination of both. However, a systemic application should also result in effective concentrations of antimicrobials in the mammary gland (Ziv, 1980; Schrickx and Fink-Gremmels, 2008). Therefore, knowledge of the main factors that could alter concentrations of relevant drugs in milk is essential in veterinary therapy for reasons of potential treatment failure or unexpected contamination of milk. Our findings are a new step toward the identification of factors which alter drug exposure in livestock and which are involved in interindividual variability. This will allow better adjustment of doses in such a way that they are high enough to guarantee efficacy and avoid the development of resistance in the

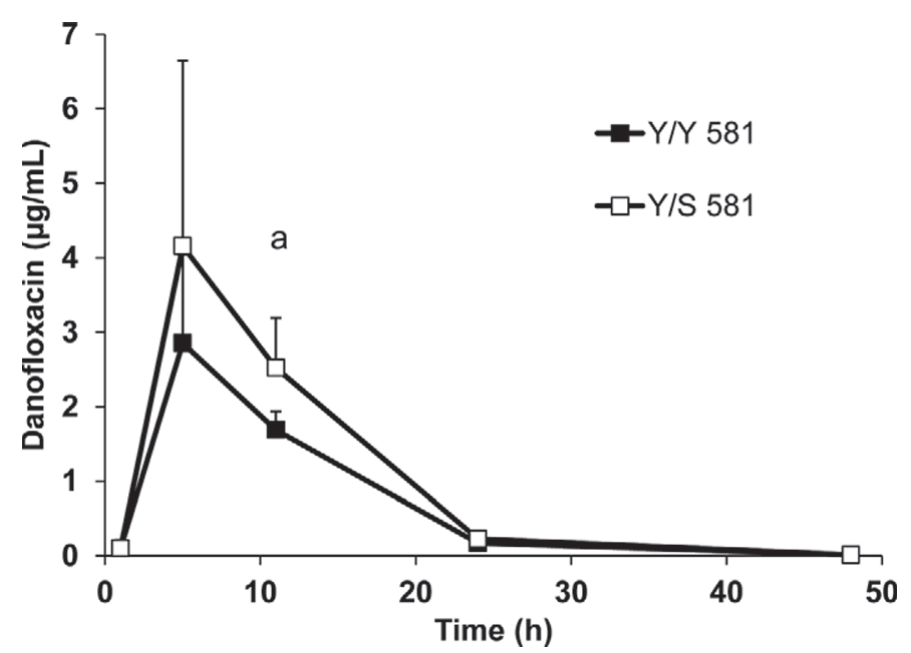

Figure 3. Milk concentrations of danofloxacin after its subcutaneous administration at a dosage of $6 \mathrm{mg} / \mathrm{kg}$ to $\mathrm{Y} / \mathrm{S} 581$ heterozygous and Y/Y 581 homozygous lactating cows genotyped for the Y581S polymorphism of the bovine $A B C G 2$ gene. Milk samples were collected at several points over $96 \mathrm{~h}$. Concentrations at 72 and $96 \mathrm{~h}$ were undetectable. The results are presented as means; error bars indicate SD. Letter a represents significant differences $(P<0.05)$ between both genotypes. $\mathrm{Y} / \mathrm{Y}$ cows $\mathrm{n}=6 ; \mathrm{Y} / \mathrm{S}$ cows $\mathrm{n}=5$. 
a)

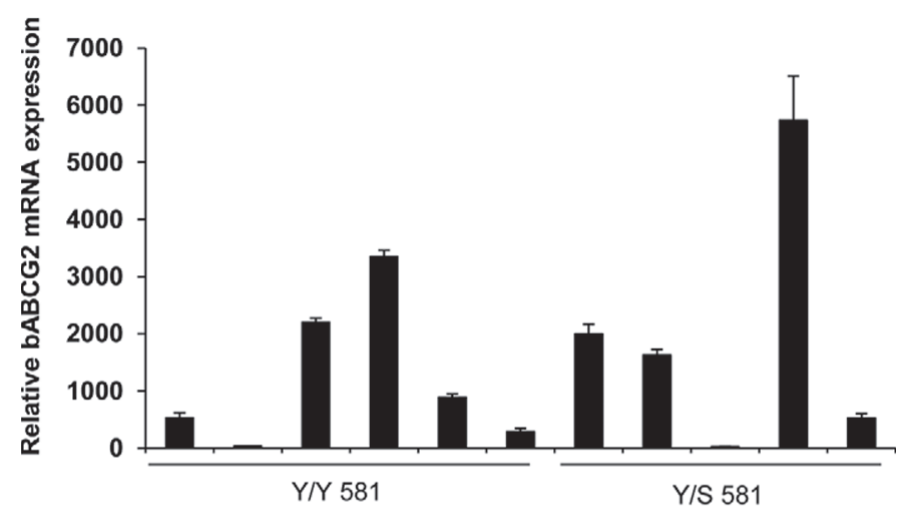

b)

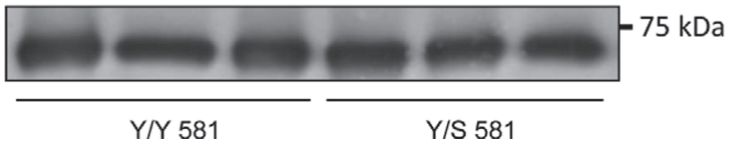

Figure 4. Relative ABCG2 mRNA (a) and protein (b) expression in cow mammary epithelial cells from $\mathrm{Y} / \mathrm{Y}$ and $\mathrm{Y} / \mathrm{S}$ individuals genotyped for the Y581S polymorphism of the bovine ABCG2 gene. The results are presented as means; error bars indicate SD. In (b), optimal protein isolation from milk fat globules was only possible for 6 animals.

animal. However, in the case of systemic infections, drug transfer into milk is undesirable. Primary control of residues is by adherence to label withdrawal period statements with the subsequent economical loss for the farmer (Seegers et al., 2003; Imperiale et al., 2009).

In conclusion, increased secretion of danofloxacin administered at the therapeutic dose of $6 \mathrm{mg} / \mathrm{kg}$ in animals carrying the Y581S ABCG2 SNP could have relevant consequences in mastitis treatment. This newly discovered factor involved in interindividual disposition variability of antimicrobials could potentially affect treatment efficacy and contribute to milk contamination.

\section{ACKNOWLEDGMENTS}

This study was supported by the Spanish Ministry of Economy and Competitiveness (Madrid, Spain) and the European Regional Development Fund (Research Project AGL2012-31116), and the Basque Government in Vitoria, Spain (predoctoral fellowship). The authors thank Salvatore Pisanu (Porto Conte Ricerche Srl, Alghero, Italy) and Garfi SAT farm (Santa Maria del Monte del Condado, Spain) for technical assistance and support. The authors are grateful to James McCue (University of Extremadura, Badajoz, Spain) for assistance in language editing.

\section{REFERENCES}

Adane, E. D., Z. Liu, T. X. Xiang, B. D. Anderson, and M. Leggas. 2012. Pharmacokinetic modeling to assess factors affecting the oral bioavailability of the lactone and carboxylate forms of the lipophilic camptothecin analogue AR-67 in rats. Pharm. Res. 29:1722-1736.

Cho, H. J., H. Yi, S. M. Cho, D. G. Lee, K. Cho, A. M. Abd el-Aty, J. H. Shim, S. H. Lee, J. Y. Jeong, and H. C. Shin. 2010. Single-step extraction followed by LC for determination of (fluoro)quinolone drug residues in muscle, eggs, and milk. J. Sep. Sci. 33:1034-1043.

Cohen-Zinder, M., E. Seroussi, D. M. Larkin, J. J. Loor, A. Everts-van der Wind, J. H. Lee, J. K. Drackley, M. R. Band, A. G. Hernandez, M. Shani, H. A. Lewin, J. I. Weller, and M. Ron. 2005. Identification of a missense mutation in the bovine $A B C G 2$ gene with a major effect on the QTL on chromosome 6 affecting milk yield and composition in Holstein cattle. Genome Res. 15:936-944.

Escudero, E., C. M. Cárceles, E. Fernandez-Varon, P. Marin, and H. Benchaoui. 2007. Pharmacokinetics of danofloxacin $18 \%$ in lactating sheep and goats. J. Vet. Pharmacol. Ther. 30:572-577.

Farke, C., H. H. Meyer, R. M. Bruckmaier, and C. Albrecht. 2008. Differential expression of ABC transporters and their regulatory genes during lactation and dry period in bovine mammary tissue. J. Dairy Res. 75:406-414.

Fukui, N., Y. Suzuki, K. Sawamura, T. Sugai, J. Watanabe, Y. Inoue, and T. Someya. 2007. Dose-dependent effects of the $3435 \mathrm{C}>\mathrm{T}$ genotype of $A B C B 1$ gene on the steady-state plasma concentration of fluvoxamine in psychiatric patients. Ther. Drug Monit. 29:185-189.

González-Lobato, L., R. Real, D. Herrero, A. de la Fuente, J. G. Prieto, M. M. Marqués, A. I. Alvarez, and G. Merino. 2014. Novel in vitro systems for prediction of veterinary drug residues in ovine milk and dairy products. Food Addit. Contam. Part A Chem. Anal. Control Expo. Risk Assess. 31:1026-1037. http://dx.doi.org /10.1080/19440049.2014.908261.

Imperiale, F., C. Farias, A. Pis, J. M. Sallovitz, A. Lifschitz, and C. Lanusse. 2009. Thermal stability of antiparasitic macrocyclic lactones milk residues during industrial processing. Food Addit. Contam. Part A Chem. Anal. Control Expo. Risk Assess. 26:5762. http://dx.doi.org/10.1080/02652030802322879.

Ito, N., K. Ito, Y. Ikebuchi, T. Kito, H. Miyata, Y. Toyoda, T. Takada, A. Hisaka, H. Honma, A. Oka, H. Kusuhara, and H. Suzuki. 2014. Organic cation transporter/solute carrier family 22a is involved in drug transfer into milk in mice. J. Pharm. Sci. 103:3342-3348.

Jonker, J. W., G. Merino, S. Musters, A. E. van Herwaarden, E. Bolscher, E. Wagenaar, E. Mesman, T. C. Dale, and A. H. Schinkel. 2005. The breast cancer resistance protein BCRP (ABCG2) concentrates drugs and carcinogenic xenotoxins into milk. Nat. Med. 11:127-129.

Kobayashi, D., I. Ieiri, T. Hirota, H. Takane, S. Maegawa, J. Kigawa, H. Suzuki, E. Nanba, M. Oshimura, N. Terakawa, K. Otsubo, K. Mine, and Y. Sugiyama. 2005. Functional assessment of ABCG2 (BCRP) gene polymorphisms to protein expression in human placenta. Drug Metab. Dispos. 33:94-101.

Komisarek, J., and Z. Dorynek. 2009. Effect of ABCG2, PPARGC1A, $O L R 1$ and $S C D 1$ gene polymorphism on estimated breeding values for functional and production traits in polish Holstein-Friesian bulls. J. Appl. Genet. 50:125-132.

Maeda, K., J. Takano, Y. Ikeda, T. Fujita, Y. Oyama, K. Nozawa, Y. Kumagai, and Y. Sugiyama. 2011. Nonlinear pharmacokinetics of oral quinidine and verapamil in healthy subjects: a clinical microdosing study. Clin. Pharmacol. Ther. 90:263-270.

Mani, O., M. T. Sorensen, K. Sejrsen, R. M. Bruckmaier, and C. Albrecht. 2009. Differential expression and localization of lipid transporters in the bovine mammary gland during the pregnancylactation cycle. J. Dairy Sci. 92:3744-3756.

Maningat, P. D., P. Sen, M. Rijnkels, A. L. Sunehag, D. L. Hadsell, M. Bray, and M. W. Haymond. 2009. Gene expression in the human mammary epithelium during lactation: The milk fat globule transcriptome. Physiol. Genomics 37:12-22. 
Martinez, M., P. McDermott, and R. Walker. 2006. Pharmacology of the fluoroquinolones: A perspective for the use in domestic animals. Vet. J. 172:10-28.

Mealey, K. L. 2013. Clinical pharmacology and therapeutics. Vet. Clin. North Am. Small Anim. Pract. 43:xi-xiii.

Merino, G., R. Real, M. F. Baro, L. Gonzalez-Lobato, J. G. Prieto, A. I. Alvarez, and M. M. Marques. 2009. Natural allelic variants of bovine ATP-binding cassette transporter ABCG2: Increased activity of the Ser581 variant and development of tools for the discovery of new ABCG2 inhibitors. Drug Metab. Dispos. 37:5-9.

Mestorino, N., M. L. Marchetti, E. Turic, J. Pesoa, and J. Errecalde. 2009. Concentrations of danofloxacin $18 \%$ solution in plasma, milk and tissues after subcutaneous injection in dairy cows. Anal. Chim. Acta 637:33-39.

Olsen, H. G., H. Nilsen, B. Hayes, P. R. Berg, M. Svendsen, S. Lien, and T. Meuwissen. 2007. Genetic support for a quantitative trait nucleotide in the $A B C G 2$ gene affecting milk composition of dairy cattle. BMC Genet. 8:32.

Otero, J. A., R. Real, A. de la Fuente, J. G. Prieto, M. Marques, A. I. Alvarez, and G. Merino. 2013. The bovine ATP-binding cassette transporter ABCG2 Tyr581Ser single-nucleotide polymorphism increases milk secretion of the fluoroquinolone danofloxacin. Drug Metab. Dispos. 41:546-549.

Pérez, M., R. Real, G. Mendoza, G. Merino, J. G. Prieto, and A. I. Alvarez. 2009. Milk secretion of nitrofurantoin, as a specific BCRP/ ABCG2 substrate, in assaf sheep: Modulation by isoflavones. J Vet. Pharmacol. Ther. 32:498-502.

Pisanu, S., S. Ghisaura, D. Pagnozzi, G. Biosa, A. Tanca, T. Roggio, S. Uzzau, and M. F. Addis. 2011. The sheep milk fat globule membrane proteome. J. Proteomics 74:350-358.

Poutrel, B., M. R. Stegemann, O. Roy, F. Pothier, N. Tilt, and M. Payne-Johnson. 2008. Evaluation of the efficacy of systemic danofloxacin in the treatment of induced acute Escherichia coli bovine mastitis. J. Dairy Res. 75:310-318.
Real, R., E. Egido, M. Perez, L. Gonzalez-Lobato, B. Barrera, J. G. Prieto, A. I. Alvarez, and G. Merino. 2011a. Involvement of breast cancer resistance protein (BCRP/ABCG2) in the secretion of danofloxacin into milk: Interaction with ivermectin. J. Vet. Pharmacol. Ther. 34:313-321.

Real, R., L. Gonzalez-Lobato, M. F. Baro, S. Valbuena, A. de la Fuente, J. G. Prieto, A. I. Alvarez, M. M. Marques, and G. Merino. 2011b. Analysis of the effect of the bovine adenosine triphosphate-binding cassette transporter G2 single nucleotide polymorphism Y581S on transcellular transport of veterinary drugs using new cell culture models. J. Anim. Sci. 89:4325-4338.

Ron, M., M. Cohen-Zinder, C. Peter, J. I. Weller, and G. Erhardt. 2006. Short communication: A polymorphism in ABCG2 in Bos indicus and Bos taurus cattle breeds. J. Dairy Sci. 89:4921-4923.

Rowan, T. G., P. Sarasola, S. J. Sunderland, C. J. Giles, and D. G. Smith. 2004. Efficacy of danofloxacin in the treatment of respiratory disease in European cattle. Vet. Rec. 154:585-589.

Schrickx, J. A., and J. Fink-Gremmels. 2008. Implications of ABC transporters on the disposition of typical veterinary medicinal products. Eur. J. Pharmacol. 585:510-519.

Seegers, H., C. Fourichon, and F. Beaudeau. 2003. Production effects related to mastitis and mastitis economics in dairy cattle herds. Vet. Res. 34:475-491.

Visser, M., M. Kayser, F. Grosveld, and R. J. Palstra. 2014. Genetic variation in regulatory DNA elements: The case of OCA2 transcriptional regulation. Pigment Cell Melanoma Res. 27:169-177.

Walsh, P. S., D. A. Metzger, and R. Higuchi. 1991. Chelex 100 as a medium for simple extraction of DNA for PCR-based typing from forensic material. Biotechniques 10:506-513.

Wojnowski, L., and J. Brockmoller. 2004. Single nucleotide polymorphism characterization by mRNA expression imbalance assessment. Pharmacogenetics 14:267-269.

Ziv, G. 1980. Drug selection and use in mastitis: Systemic vs local therapy. J. Am. Vet. Med. Assoc. 176:1109-1115. 